\title{
Technological Dramas and the Punjab Police: The Downfall of Front Desk
}

\author{
Muhammad Shahid ${ }^{1, *}$ \\ Department of Computer Science, Virtual University of Pakistan \\ M.A. Jinnah Campus, Defence Road, Off Raiwind Road, Lahore, Pakistan \\ Tel: +92-345-7483688 E-mail: shahidrao739@gmail.com \\ Tariq Abbas Qureshi ${ }^{2}$ \\ Police Service of Pakistan \\ Lahore, Pakistan \\ Tel: +92-300-9554011 E-mail: tariqabbas1967@gmail.com \\ Talha Farooq Khan ${ }^{3}$ \\ Department of Computer Science, The Islamia University of Bahawalpur \\ Hasilpur Rd, Bahawalpur University, Bahawalpur, Punjab, Pakistan \\ Tel: +92-344-3079010 E-mail talhafarooqkhan@gmail.com \\ Muhammad Saleem ${ }^{4}$ \\ Department of Computer Science, Virtual University of Pakistan \\ M.A. Jinnah Campus, Defence Road, Off Raiwind Road, Lahore, Pakistan \\ Tel: +92-345-5756174 E-mail msaleem334@gmail.com \\ Sadia Parveen ${ }^{5}$ \\ Department of Zoology, The Islamia University of Bahawalpur \\ Hasilpur Rd, Bahawalpur University, Bahawalpur, Punjab, Pakistan \\ Tel: +92-344-6693592 E-mail drsomi77@gmail.com
}

\begin{abstract}
Electronic dependence and utilization have been emerging as one of the driving forces towards departmental growth and development in this new era of globalization and modernization in Punjab police. The Front Desk (FD) project has a sign of change in Punjab police. It was changing the face of the police from the very first day it was started, but with the passage of time, it has changed its motive and began to change in the color of police. Hence, this paper highlights the issues and their solutions regarding the implementation and utilization of the FD project in the Punjab police department. It also highlights the working of Punjab police with and without FD and the importance of FD in the police department to delivering the grievance and of analysis the true nature of crimes. It discusses various aspects of police department myths and mistakes undertaken by the Punjab police officials and suggests various solutions for changing the face of the department.
\end{abstract}

Keywords: Front Desk Project, Information Technology, Police Culture, Policing, Police Myths, Working of FD, Training \& Development.

DOI: $10.7176 /$ PPAR/11-1-07

Publication date: February 28th 2021

\section{INTRODUCTION}

In Punjab police, Front Desk (FD) project was initially started with 10 police stations in Lahore in 2015. In 2016, authorities have given the name FD and extended it to more than 200 police stations in 13 districts, that department has established FD in every single police station across Punjab. FDs being run by the civilian staff (Font Desk, 2018) were rapidly changing the face and act as the bridge and shorten the distance between public and police but as time being it is changing its face and becoming useless to the public. The basic aim of FD was to provide a pleasant environment to the complainants at police stations so that they can file complaints without any fear and hesitation also organized mechanism to address grievances of the citizens. Paperless policing is the vision of the high-ups in the Punjab police department. Owing to human discretion, unnecessary file, and inordinate delays, the erstwhile manual system of complaint redress had lost its efficacy to resolve the issues of the public. The failure of manual complaint management was in turn undermining the cause of justice and public service (CMS\&PSRMS, 2018). The post and pre working in police stations regarding complaint handling with and without FD are defined in Figures 1 and 2 respectively. 
Figure 1: Manual Complaint Handling System in Police Station

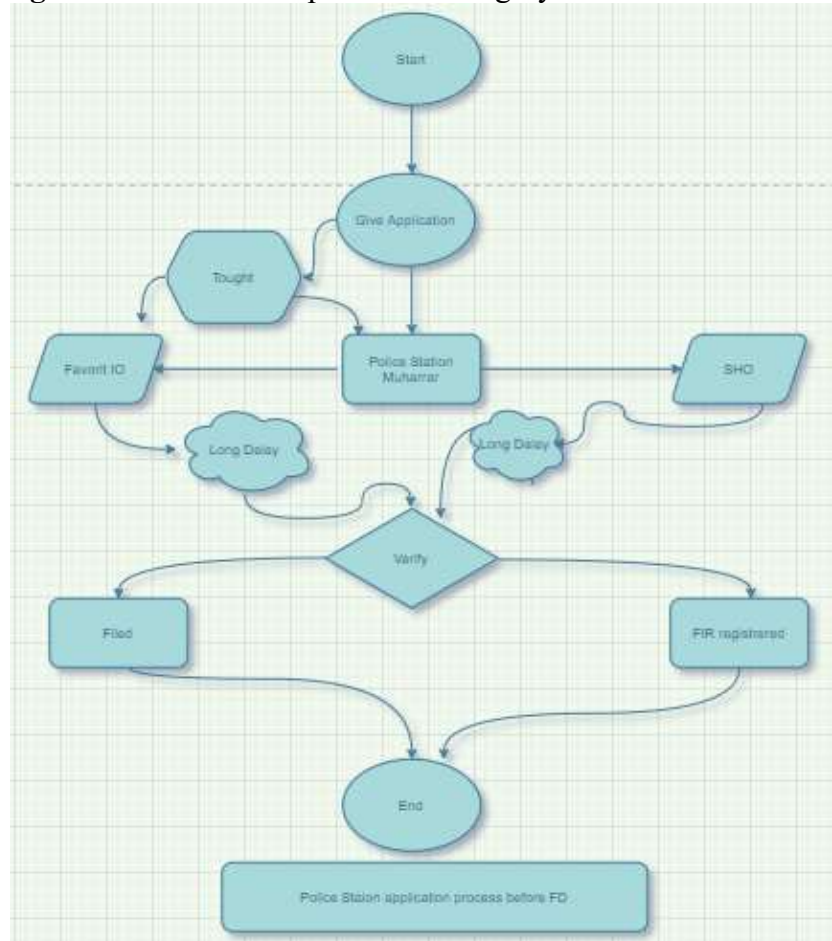

Figure 2: FD Complaint Management System in Police Station

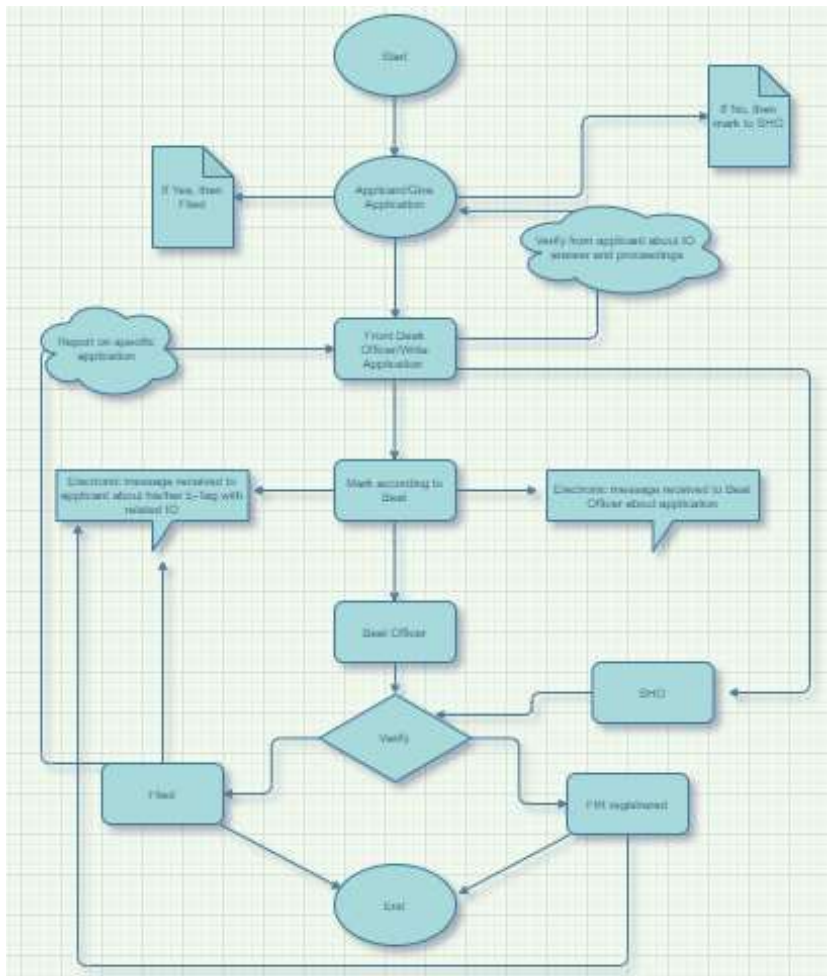

As shown in figure 1, the purpose for which the FD system was created is losing its worth and originality (figure 2). The trust of the general public, as well as the motive of the change in the police department, is severally damaging and the police department is returning to its old form. The below figure shows the working of police stations before FD in police department is as follows 
Figure 3: Police Communication System

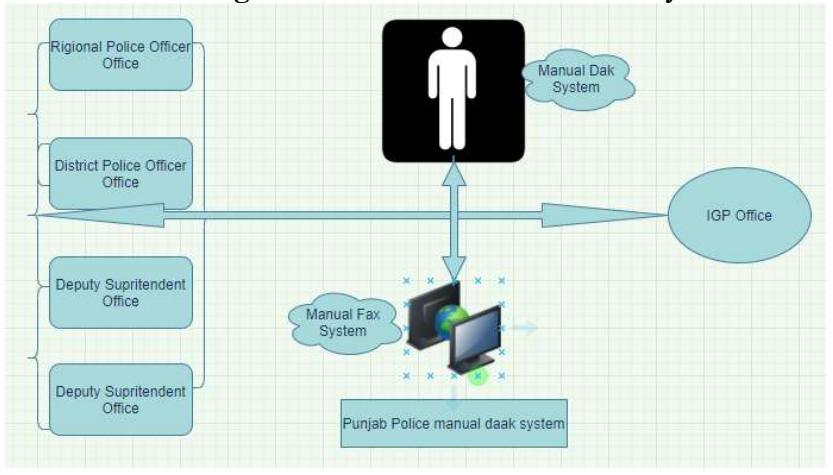

\section{AIM}

This study will investigate the working of police affairs with and without the FD project. We'll discuss the police department before and after the FD system and how this beneficial system is on the verge of destruction. Later on, we'll propose a deliverance \& revolt model that will help to tackle the situation and will improve the working of the FD project.

\section{UNDERSTANDING THE TECHNOLOGICAL AND CULTURAL CHANGE IN POLICE}

FD was a change in the police department. Police is not a department where people adopt new things easily and the same happen with this initiative. Commonly, police performance based on crime prevention, detection, security, and solving public grievances but where everything is monitoring or recording somewhere and keeping an eye electronically on the performance of police officers was a tough call. Mostly police work after something went wrong is based on two words, "Shafqat (Appendix) A" and Taki $^{\mathrm{B}}$ " and somehow these words are the main cause of the bad performance of the police department. Police behavior is dependent on political, social $\&$ domestic problems and the mindset that the police department has right now and was before didn't accept the FD project because there's a number of factor that must be taken into account in order to manipulate data systematically.

Sparrow has long emphasized the importance of managing information systems properly: "If badly managed, they can frustrate managerial purposes, enshrine old values, focus attention on outdated and inappropriate performance measures, give power to the wrong people, cast in concrete old ways of doing business, create false or misleading public expectations, destroy partnerships and impose crippling restrictions to new styles of operation quite apart from their propensity to consume millions and wasted millions of tax" (Sparrow, 1991: $\underline{26)}$

Examples of technical and implementation problems of information technology in policing include flaws in system design which resulted in data of poor quality and the failure to build and maintain support for technology within police departments (

Figure 4: Organizational Performance Factors

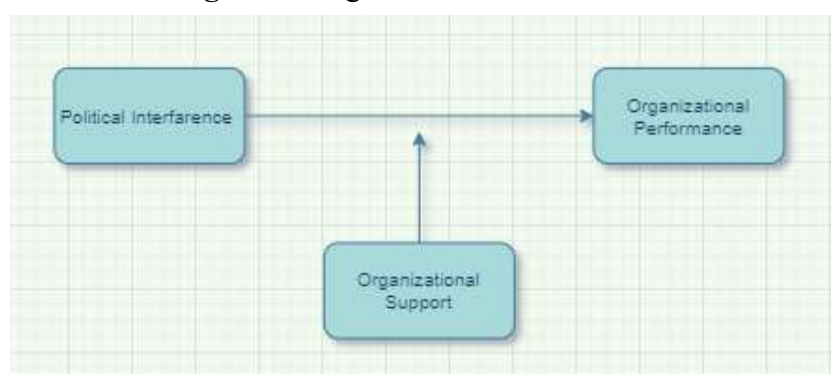

Organizational performance is defined as a measure of how an organization is managed well and how an organization can deliver value to its customers and stakeholders (Moullin, 2007).

\section{CULTURAL FACTORS}

Technology is not simply an objective, physical given; people have to make sense of it and, in the process, 'develop particular assumptions, expectations, and knowledge of the technology, which then serve to shape subsequent actions toward it' (Sovacool \& Sovacool, 2019). 
The introduction of new technology is merely the beginning of a 'technological drama' (MANNING, 1992) of normalization, adjustment, reconstitution and reintegration.

The police subculture may contain organized subgroups that may have strongly influenced the character of the larger entity. They're people in the police who may be grouped on the basis of age, educational attainment, rank, sex, and length of service. Among these there may be a person of distinctive language, extroverts, married, introverts, single, values, beliefs, and variations in mental health and stereotypes; some are based on rumor hearsay and physical structure (Trinkner et al., 2019). Punjab police's district's Supervisory Officer's (SO) fact information and complaint resolution system is mainly based on lie.

\section{LITERATURE REVIEW AND THEORATICAL BACKGROUND}

Hassle-free and paperless policing is the hall mark of the developed world countries like India _(Ewart, 1935) and UAE are also using the latest gadgets and technologies to make their police public-friendly and efficient (Chattha et al., 2019). Gone are the days when police station clerks had to beg complaints about stationery, fuel, and food. Now, the front desks being run by civilian staff are rapidly changing the face of the police force because the station assistants are given all accessories - ranging from printers to Wi-Fi and android handsets to water dispensers. Above all, they work in air-conditioned rooms (Front Desks Changing Police Face, 2016).

Registering a First Investigation Report (FIR) obligates the police to investigate a complaint, but getting the police to accept an FIR from an average citizen generally requires the intervention of a senior police officer or influential person and the payment of a bribe (Applicants et al., 2013). So, to cater to a situation like this, the police need a centralized monitoring system that brings the idea of the FD.

Unlike advanced Western countries, stability in Pakistan is, therefore, not maintained through transparent redistribution of resources but the chain of patronage right from the parliamentarians down to the people. As (Malik $\underline{\& \text { Qureshi, 2020) }}$ demonstrated in their article, police corruption, becomes an institutionalized and legitimized phenomenon.

IT has become increasingly integrated into modern police organizations, driven by its potential to improve the effectiveness of operations and generate cost savings. These included records management, dispatch, crime investigation, personnel records, information sharing, fleet management, automated booking, and resource allocation systems (Jackson et al., 2011).

The taxonomy of electric police is as follows,

Figure 5: Taxonomy of Electronic-Police

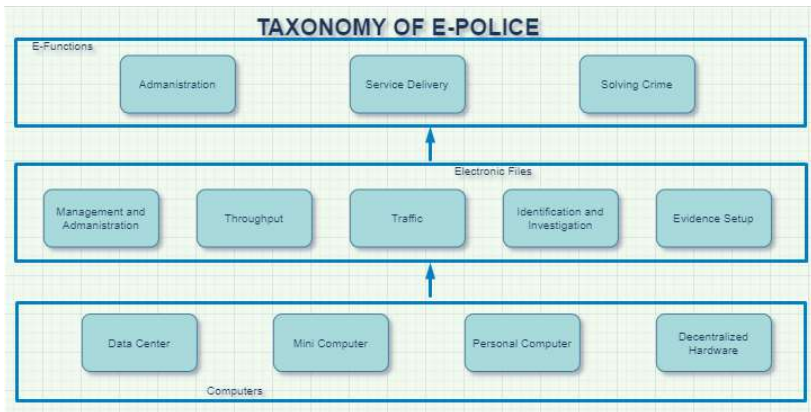

FDs details across Punjab are as follows

\begin{tabular}{|c|c|c|c|c|c|}
\hline District & PS & FD & District & PS & FD \\
\hline Lahore & 84 & 84 & Bhakhar & 11 & 11 \\
\hline Sheikhupura & 16 & 16 & Rawalpindi & 30 & 30 \\
\hline Nankana Sahib & 11 & 11 & Attock & 14 & 14 \\
\hline Gujranwala & 30 & 30 & Jhelum & 11 & 11 \\
\hline Hafizabad & 10 & 10 & Chakwal & 11 & 11 \\
\hline
\end{tabular}




\begin{tabular}{|c|c|c|c|c|c|}
\hline Gujrat & 23 & 23 & Sahiwal & 17 & 17 \\
\hline M.B. Din & 11 & 11 & Okara & 19 & 19 \\
\hline Sialkot & 27 & 27 & Pakpatan & 12 & 12 \\
\hline Narowal & 14 & 14 & Multan & 32 & 32 \\
\hline Faisalabad & 41 & 41 & Lodhran & 10 & 10 \\
\hline Jhang & 14 & 14 & Khanewal & 18 & 18 \\
\hline Chiniot & 9 & 9 & Vehari & 19 & 19 \\
\hline Toba Tek Singh & 11 & 11 & Dera Ghazi Khan & 18 & 18 \\
\hline Sargodha & 27 & 27 & Rajanpur & 16 & 16 \\
\hline Khushab & 9 & 9 & Muzaffargdh & 21 & 21 \\
\hline Mianwali & 19 & 19 & Layyah & 8 & 8 \\
\hline Bahawalpur & 24 & 24 & Rahim Yar Khan & 27 & 27 \\
\hline Bahawalnagar & 22 & 22 & Kasur & 20 & 20 \\
\hline
\end{tabular}

The district-wise total police stations and FD details are given above as approximately 716 police stations are in Punjab and the same number of FDs is being established in each police station of Punjab.

Background Steps on to reform Punjab police to curb crime effectively. Manifold steps are taken to reform the Punjab police department and improve its ability to combat crime with the help of information technology, digitalizing its manual functions that have become obsolete and useless (Front Desk in Punjab Police, 2018).

\section{RESEARCH QUESTIONS}

- What is FD in the Punjab police department?

- How FD working?

- How FD is beneficial for the public and police?

- Why FD project is losing its worth and motive?

- What problems do FD officials are facing?

- How FD project could be as it was on the first day?

\section{RESEARCH METHOD AND DATA COLLECTION}

\subsection{RESEARCH STRATEGY}

The research strategy adopted for the study is "Qualitative". This is a set of non- statistical inquiry techniques and processes used to gather data about something, may it be a social phenomenon or an organizational structure (McNabb, 2013).

\subsection{RESEARCH DESIGN}

An explanatory research design has been used for this study. This design is used in a qualitative study to explore any phenomenon and to develop a causal explanation of something i.e. cause of the consequence of interest (McNabb, 2013).

6.3 DATA COLLECTION

Different stakeholders had been identified for this study in order to get a comprehensive view of the issue regarding the downfall of FD and for this purpose in-depth interview, questionnaires, observations and focus group meetings have been conducted with the respondents with the help of the convenient Sampling strategy. Stakeholders and respondents belong to the following sections of the society:

- $\quad$ Serving and retired police Officials

- $\quad$ Serving and resigned FD Officials

- Legislators(Parliamentarians) Members of the Provincial Legislature were interviewed, because in Pakistan Law and Order is a provincial subject

- $\quad$ Print and Electronic Media Journalists

- General Public and Applicants

1961 questionnaires ( 2 parts) were sent to above mentioned stakeholders around the Punjab, out of which 1508 questionnaires were received which makes $76.9 \%$ response rate. In addition, before sending the survey questionnaire for actual data collection a pilot study has been conducted with 23 Data Processing Officer's (DPOIT) to confirm the reliability and validity of the instrument using Cronbach's alpha (Williams et al., 2012). 


\begin{tabular}{|c|c|c|c|c|}
\hline \multicolumn{2}{|l|}{ No. } & $\begin{array}{c}\text { Sent Number of } \\
\text { Mails }\end{array}$ & $\begin{array}{c}\text { Received Number of } \\
\text { Mails }\end{array}$ & Received \% \\
\hline 1 & FD Officials & 639 & 559 & 87.5 \\
\hline 2 & Police Officials & 578 & 325 & 56.2 \\
\hline 3 & Parliamentarians & 13 & 4 & 30.8 \\
\hline 4 & Media Persons & 26 & 17 & 65.4 \\
\hline 5 & General Public & 705 & 603 & 85.5 \\
\hline & Total & 1961 & 1508 & 76.9 \\
\hline
\end{tabular}

Graph 1: Questionnaire Bifurcation

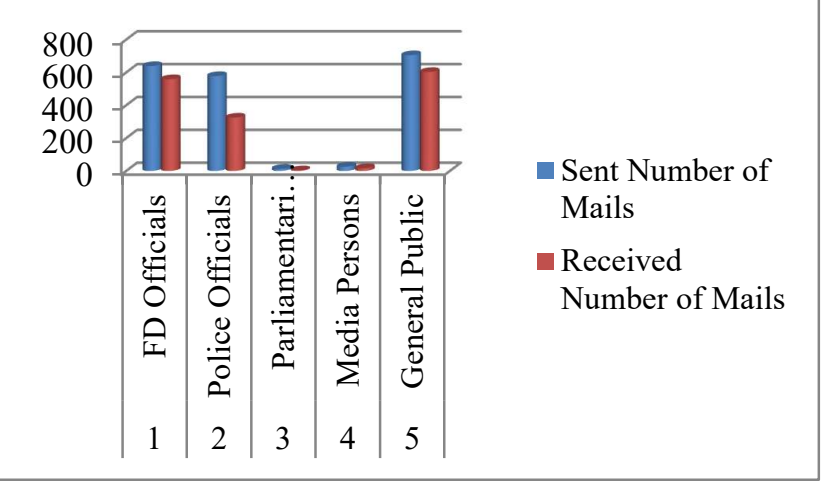

Another part of the survey received with the responds rate is as follows

\begin{tabular}{|c|c|c|c|c|c|}
\hline & SA & A & SD & D & N\&N/A \\
\hline Police Officials & 27 & 115 & 19 & 147 & 17 \\
\hline Parliamentarians & 0 & 1 & 0 & 2 & 1 \\
\hline Media Persons & 3 & 4 & 3 & 6 & 46 \\
\hline General Public & 8 & 23 & 178 & 348 & 65 \\
\hline
\end{tabular}


Graph 2: Questionnaire Answers Bifurcation

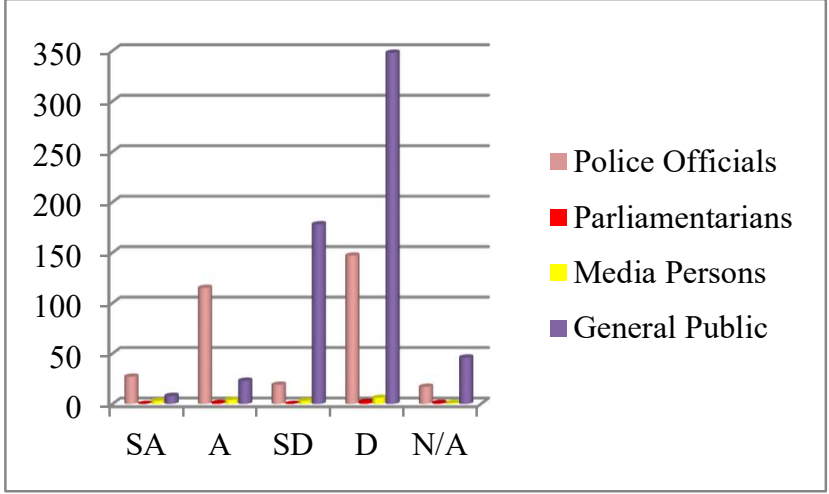

Below figure shows that $68 \%$ FD officials are being working in police department is not satisfy with their jobs, which should be an alarming situation for police supervisory, public and as well as government.

Graph 3: FD Officials Response

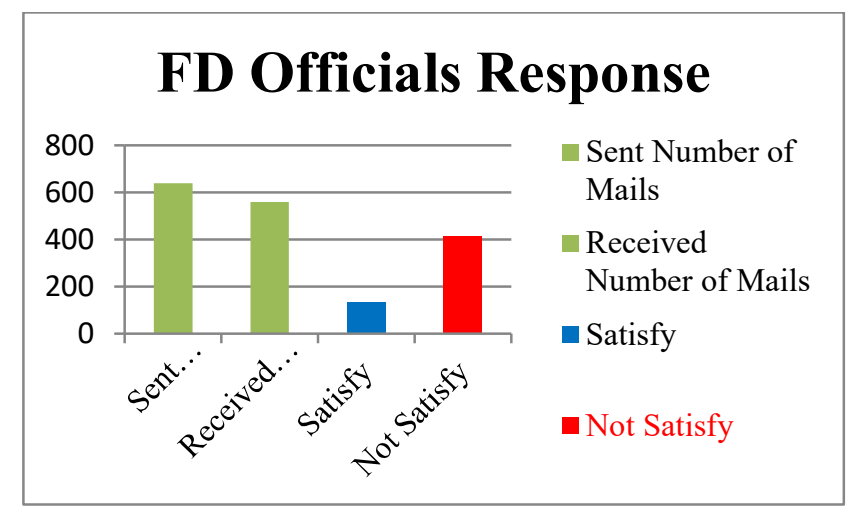

\subsection{IMPACT OF FD ON POLICE PERSONAL}

With the introduction of the FD project in the police, police think they're being bound to something which is apart from the high-ups.

\section{THE FD WORK: THEORETICAL FRAMEWORK}

The concept of FD has its genesis in the fact that the common man is hesitant to step into a police station. This system provides a "single point of access" or the "one window operation" to the citizens so that they could lodge a complaint or find out the status of their cases without any inconvenience.

The framework model shown below figure includes the eight (8) independent variables, which are departmental reforms, transfer posting policy, police myths, software bugs, the performance of FD officials and SO's, implementation of SOP, and independence, which predict the downfall of FD through moderating role of organizational support. Figure 6: Theoretical Framework

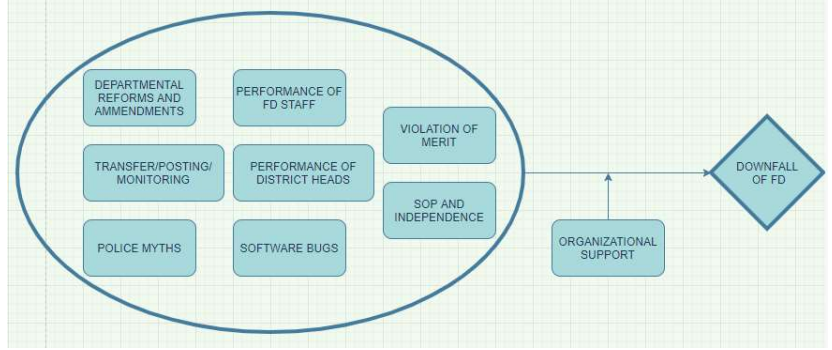

\subsection{PERFORMANCE OF SUPERVISORY POLICE PERSONALS}

With the beginning of FD in the police, it also has some drawbacks in terms of manipulating the crime figures. A number of factors continue to weaken this endeavor; the performance of each supervisory is partially based on misinterpreting and hiding crime figures. Violation of merit, not knowing about the SOP of FD, listening 
to rumors hearsay, playing in the hands of conspiratorial lobbies, all in all mentality and, somehow, immaturity are the main factors in the downfallen of the FD project. A few dealing hands pressurize FD officials in different ways to enter hypothetical data. Ultimately, a question comes to mind that how it is possible for a person to get renewed his/her contract and can work on merit by not abiding the directions regarding data manipulation. The district they trying to fix its record- have to send their contract extension to high ups.

7.2 PERFORMANCE OF DPO-IT/HARWARE NETWORK TECHNICIAN (HNT)/SENIOR STATION ASSITANT (SSA) \& POLICE STATION ASSISTAN (PSA) - FD OFFICIALS: CAUSES AND RESULTS

In this study, we also have to look at the performance of the different end users of the FD project. The officials of the FD project known as DPO-IT/HNT/SSA/PSA also have a hierarchy in terms of scale and salary mentioned as the names from senior to junior. The main role in the FD project is of SSA and PSA; they've to enter all the data timely and accurately. Unfortunately, they've failed to perform their duties as they lost their interest in the job. Moreover, not interested in the writings of the citizen's applications, office times, behavior, room decorum, dress code, lack of honor-ship, lack of responsibility, zero feedback from FD applications and data entry quality are the main reasons for FD personals to FD project. That because of the insecurity of job, service structure, geographical issues, coordinate with the police station staff, lack of support from district's supervisory, favoritism, lobbying, salary, timing, non-interested behavior from high ups, conflict in SOP and most important departmental threats. Above all these things are down-falling the morale of FD staff. The FD supervisory should not be dependent on the district supervisory as they're being faced with many issues at the district level. This project is going on the road of dead-end, after some time police will see as this project will produce the garbage in terms of data.

\subsection{NON ACCEPTANCE BEHAVIOUR FROM BELT FORCE}

For the success of any new project, it has to be accepted by the peoples who are working in that department. FD is not an ideal project for belt force. The theme that FD has is against the interest of Muharrar \& Station House Officer (SHO). Discrimination towards FD officials is also a big factor in this regard. Punjab police use discrimination when it comes to FD officials. We'll say this with an apology that Punjab police unwelcomed this innovative change in this department. Police personals said, "The day when FD came into the police department, it's destroyed the department". FD officials are "Light Creatures". Belt force thinks that like other initiatives in past taken by the department were closed, FD will also be closed. Some of the high ups think that "if we support them, one day they'll go far ahead and leave us behind". As per belt force, the FD project exploiting the rights of the belt force.

\subsection{POLICE MYTHS}

Public think, if we give application to these civil staff of police, our application might be through in the dustbin, belt force did the proceeding so we'll give our application to the Muharrar because nothing happened in police without a bribe. As per the police staff, "if citizen will give the application at FD then we'll not proceed but if you'll give application directly to us (Muharrar/SHO) then we'll proceed. Another thing is police think with their experience and per citizen's applications that $90 \%$ of applications based on a lie. It might be true for violent applications but not for property crime as we'll see this is in the below section.

\subsection{INEFFECTIVENESS OF COMPLAINT MANAGEMENT SYSTEM (CMS)}

As CMS is Police's primary/basic software; Police need to be more focused on it. The applicants who are not satisfied with Police Stations then resort to different channels like PMDU, CM Portal, 8787, etc. While focusing on CMS, they can minimize the bulk of applications at different forums. Police's job is not only to protect the citizens but also to hinder domestic violence to maintain peace among society. According to the official figures, the police force is failing to combat crime effectively (International Crisis Group, 2008) it also has failed to protect society from crime against property of one (1) district as shown in the below analysis of registered applications on FD and registered First Investigation Reports (FIRs). 


\begin{tabular}{|c|c|c|c|c|}
\hline & $\mathbf{2 0 1 7}$ & $\mathbf{2 0 1 8}$ & $\mathbf{2 0 1 9}$ & $\mathbf{2 0 2 0}$ \\
\hline $\begin{array}{c}\text { TOTAL REGISTERED } \\
\text { APPLICATIONS AT FD OF } \\
\text { CRIME AGAINST PROPERTY }\end{array}$ & 3340 & 7495 & 9135 & 12771 \\
\hline FILED & 1833 & 5627 & 6152 & 9163 \\
\hline REGISTERED FIR & 1507 & 1868 & 2982 & 3393 \\
\hline FILED PERCENTAGE \% & 54.9 & 75.1 & 67.3 & 71.7 \\
\hline
\end{tabular}

With the rising crime figures, nationwide, the numbers are not good as they appear (Laeeq et al., 2016).

Graph 4: CMS Statistics

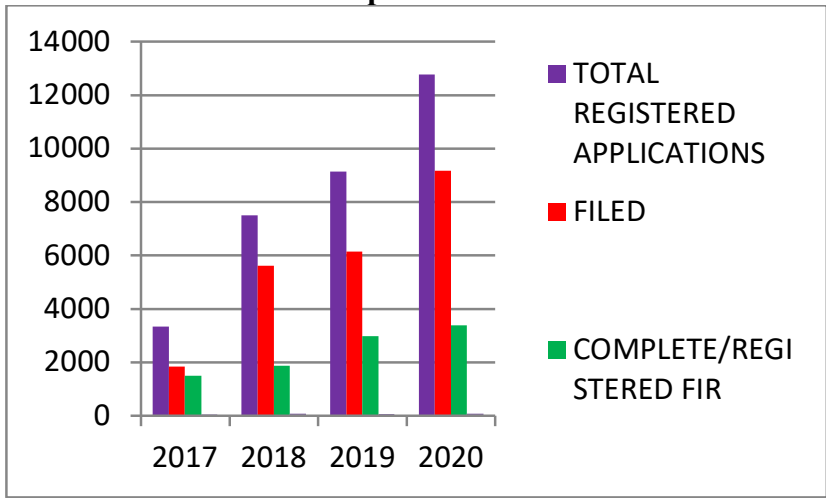

\subsection{DID CRIME DROP OR DID WE DROP THE BALL?}

As time on the run, crime is increasing day by day. When we saw the above analysis, it is also an eyeopener for government officials and high ups, we've seen that every year registered and not registered crime is increasing and the hidden, dark and non-reported crime is another issue. We know that every application is not based on truth, suppose, if we deduct 50\% applications (frivolous, nominated, duplicated) of crime against property which is quite impossible then the remaining 50\% FIRs should be registered but facts are quite the opposite. Applicants are not mad that they give property application without being robbed. It shows that CMS could not meet the expectations of the citizens. Police didn't register FIRs properly on crime against property. Due to a lack of financial resources for FD management, the administration is also being criticized for providing stationery and other technical facilities (Front Desk employees, 2016). Now, we can say that the FD is useless. FD personals are also not following SOP for CMS which makes it vulnerable.

7.7 FD SOFTWARE BUGS

As per the FD officials, bugs in the FD software's are another hurdle in the progress of this project. It might be a business for the development team, their attention to keep delaying the modification on the development side to secure their assignment and to stick with the department.

\subsection{DEPARTMENTAL REFORMS AND AMMENDMENTS}

Police need departmental reforms to save the FD project. Job insecurity is a key element among FD officials. Even after five years, the Punjab police have failed to form a service structure for FD employees owing to selfish concerns (Front Desk employees, 2016).

FD employees informed that they're serving in the police department for the last 5 years; however, the department has failed to regularize their services.

The police department should regularize the FD officials and made requisite amendments in police rule to keep alive this project. FD staff claims regarding the pay scale, service structure, and other facilities were made by the higher-ups during the appointment, but now despite the lapse of more than five years, due to the unavailability of service structure, they are still on a contract basis.

\subsection{DEPATMENT NEEDS TRAINING: ETHICAL AND PROFESSIONAL}

There is a need of professionalism and continuous ethical training in the Police department. Verbal training and exam sessions should be conducted about their Job Description (JD). Seniority, experience, and maturity level should be considered while posting SO's. SO must know about the SOP of FD and the hierarchy of 
command. Even after five years, mostly police officials didn't know anything about the FDs SOP and chain of command. Tragically, high-ups and district heads don't bother to see FD's SOP. There is in dire need to implement the JD of FD supervisory in the district to animate the FD project.

FDs SOP should be clear, precise, and disseminate from time to time within the department. Monitoring should be on merit and on time to avoid the untoward situation regarding FD affairs.

\subsection{TRANSFER/POSTING OF FD OFFICALS}

In the police department transfer posting is an issue from the first day and it is the root of all troubles. Transfers posting of FD officials are not being made on merit. Apart from the FD's SOP, FD officials are being posted on different branches, resultantly; cause of the FD is being compromised, which leads to promoting favoritism.

\subsection{MONITORING AND SCALING OF FD OFFICALS}

The police department is based on fear like the criminal's department. Researchers have linked police officers' concerns with appearing racist a kind of stereotype threat to racial disparities in the use of force. Their study hypothesized that stereotype threat undermines officers' self-legitimacy or the confidence they have in their inherent authority, encouraging overreliance on coercive policing to maintain control (Trinkner et al., 2019). As per the proposed scales of the FD officials, DPO-IT/HNT/SSA/PSA will be as 16/14/9 and 7 respectively, which is not enough to do their job and to deal with the police officials. Their supervisory must have a gazetted scale and the SSA/PSA should have 14/12 scales in the district to be held accountable for the official affairs. FD supervisory should be working under the command of Regional Police Officer (RPO) after Central command. Through this, district supervisory will handle FD affairs in an appropriate manner when they have the authority with a separate chain of command.

\section{CMS MONITORING}

By keeping in mind the importance of the CMS in the Police Department and report generation for analysis of different crime heads/sections/categories, a reporting system is proposed. Police are warranted by the government to enforce the law by arresting criminals and detecting the nature of the crimes through CMS. Because keeping the peace is a primary need of society, the police are around us since civilization began. Police usually and can timely be viewed as heroes within our community due to the often dangerous situations they encounter in service to the public; CMS is one of them to help the police department to portray a better image in the society.

The Electronic Tag (E-Tag) system (Police Initiative, 2016), that police are using is not enough mature to produce reports more appropriately. Here, we're proposing a report generation system to generate E-tags at Front Desks in an appropriate view that can help police in proper report generation on a single click.

E-Tag must be generated against crime head wise, i.e. In Reporting of Crime, there should be only below heads,

- Crime Against Property

- Crime Against Person

- $\quad$ Local \& Special Law

- Miscellaneous

- Investigation

- Loss Report

- Character Verification

\section{- Reporting of Crime}

\begin{tabular}{|c|c|c|}
\hline Category & Offense & Offense Subcategory \\
\hline \multirow{4}{*}{ Crime Against Person } & \multirow{3}{*}{ Murder } & Murder \\
\cline { 2 - 3 } & & Murder Intension \\
\cline { 2 - 3 } & & Cause/Mistake \\
\cline { 2 - 3 } & Attempted Murder & Attempted Murder \\
\cline { 2 - 3 }
\end{tabular}




\begin{tabular}{|c|c|c|}
\hline Category & Offense & Offense Subcategory \\
\hline & Attempted Suicide & Attempted Suicide \\
\hline & \multirow{2}{*}{ Hurt } & Unserious \\
\hline & & Serious \\
\hline & Acid Throwing & Acid Throwing \\
\hline & \multirow{5}{*}{$\begin{array}{l}\text { Kidnapping/ kidnapping for } \\
\text { ransom/ } \\
\text { Kidnapping for adultery }\end{array}$} & Kidnapping \\
\hline & & 365 \\
\hline & & $365-\mathrm{A}$ \\
\hline & & $365-\mathrm{B}$ \\
\hline & & 496-A \\
\hline & \multirow{2}{*}{ Rape } & 376 \\
\hline & & Minor \\
\hline & Gang Rape & Gang Rape \\
\hline & Rioting & Rioting \\
\hline & \multirow{2}{*}{ Accident } & Deadly \\
\hline & & Non-Fatal \\
\hline & Police Competition & Police Competition \\
\hline & \multirow{2}{*}{ Resistance } & Police \\
\hline & & Govt. Servant \\
\hline & Extortion & Extortion \\
\hline & Other & Other \\
\hline \multirow{30}{*}{ Crime Against Property } & \multirow{6}{*}{ Dacoity } & Shop \\
\hline & & House \\
\hline & & Motor Cycle \\
\hline & & Car \\
\hline & & Other Vehicle \\
\hline & & Other Dacoity \\
\hline & & Shop \\
\hline & & House \\
\hline & & Motor Cycle \\
\hline & Robbery & Car \\
\hline & & Other Vehicle \\
\hline & & Other Robbery \\
\hline & & Motor Cycle \\
\hline & & Car \\
\hline & 382 PPC & Other Vehicle \\
\hline & & Other 382 PPC \\
\hline & & $457 / 380$ \\
\hline & & $458 / 380$ \\
\hline & Theft & 459 \\
\hline & & 460 \\
\hline & & Car \\
\hline & $381-\mathrm{A}$ & Motor Cycle \\
\hline & & Other \\
\hline & & Theft \\
\hline & & Cattle \\
\hline & Theft & Mobile Phone \\
\hline & & Tree \\
\hline & 356 & 356 \\
\hline & PPC411 & PPC411 \\
\hline & Dacoity/Robbery with Murder & Dacoity with Murder \\
\hline
\end{tabular}




\begin{tabular}{|c|c|c|}
\hline Category & Offense & Offense Subcategory \\
\hline & Other Property & Other Property \\
\hline \multirow{34}{*}{ Local \& Special Law } & Beggar Act & Beggar Act \\
\hline & Kite Flying Act & Kite Flying Act \\
\hline & Police Order 2002 & Police Order 2002 \\
\hline & Fourth Scheduler & Fourth Scheduler \\
\hline & Stock & Stock \\
\hline & Wall Chalking Act & Wall Chalking Act \\
\hline & Slaughter Act & Slaughter Act \\
\hline & Money Landing & Money Landing \\
\hline & Pesticide Act & Pesticide Act \\
\hline & Fake Fertilizer & Fake Fertilizer \\
\hline & 16-MPO & 16-MPO \\
\hline & Petroleum Act & Petroleum Act \\
\hline & Canal and Drainage Act & Canal and Drainage Act \\
\hline & Child Labour Act & Child Labour Act \\
\hline & Ramazan Act & Ramazan Act \\
\hline & Price Control & Price Control \\
\hline & University and Board Act & University and Board Act \\
\hline & One Wheeling & One Wheeling \\
\hline & Security Ordinance & Security Ordinance \\
\hline & Sound System & Sound System \\
\hline & Temporary Residents Act & Temporary Residents Act \\
\hline & Mineral Act & Mineral Act \\
\hline & 97-A MVO & 97-A MVO \\
\hline & Telegraph Act & Telegraph Act \\
\hline & Drugs Act & Drugs Act \\
\hline & Wild Life Act & Wild Life Act \\
\hline & Food Act & Food Act \\
\hline & Obedience Act & Obedience Act \\
\hline & $11 \mathrm{PO}$ & $11 \mathrm{PO}$ \\
\hline & 9/A-B-C & 9/A-B-C \\
\hline & Gambling Act & Gambling Act \\
\hline & Arms Ordinance & Arms Ordinance \\
\hline & Complaint against Police & Complaint against Police \\
\hline & Other Local \& Special Law & Other Local \& Special Law \\
\hline \multirow{14}{*}{ Miscellaneous } & 186 & 186 \\
\hline & Cheque Dishonor & Cheque Dishonor \\
\hline & Fake Currency & Fake Currency \\
\hline & Fake Documents & Fake Documents \\
\hline & 216 & 216 \\
\hline & 212 & 212 \\
\hline & Escape from Police Custody & Escape from Police Custody \\
\hline & Illegal Custody & Illegal Custody \\
\hline & 341 & 341 \\
\hline & Interference 452 & Interference 452 \\
\hline & $\begin{array}{l}354 \text { Outraging the Modesty of } \\
\text { Women }\end{array}$ & $\begin{array}{l}354 \text { Outraging the Modesty of } \\
\text { Women }\end{array}$ \\
\hline & Breach of Trust & Breach of Trust \\
\hline & Fraud & Fraud \\
\hline & Fake Government Servant & Fake Government Servant \\
\hline
\end{tabular}




\begin{tabular}{|c|c|c|}
\hline Category & Offense & Offense Subcategory \\
\hline & Electricity Act & Electricity Act \\
\hline & Sui Gas Act & Sui Gas Act \\
\hline & Over speeding & Over speeding \\
\hline & Fireworks Act & Fireworks Act \\
\hline & $285 / 286$ & $285 / 286$ \\
\hline & Gas Refilling Act & Gas Refilling Act \\
\hline & Preparation of Dacoity & Preparation of Dacoity \\
\hline & Damage & Damage \\
\hline & Secret Birth & Secret Birth \\
\hline & 188 & 188 \\
\hline & $506-\mathrm{B}$ & $506-\mathrm{B}$ \\
\hline & 294 PPC & 294 PPC \\
\hline & $367 \mathrm{~A} / 377$ & $367 \mathrm{~A} / 377$ \\
\hline & Brothel & Brothel \\
\hline & Water Act & Water Act \\
\hline & Child Marriage Act & Child Marriage Act \\
\hline & Blasphemy & Blasphemy \\
\hline & $\begin{array}{l}\text { Outraging the Modesty of } \\
\text { Women }\end{array}$ & $\begin{array}{l}\text { Outraging the Modesty of } \\
\text { Women }\end{array}$ \\
\hline & Child Abuse & Child Abuse \\
\hline & Gender Abuse & Gender Abuse \\
\hline & Minority Abuse & Minority Abuse \\
\hline & Human Rights & Human Rights \\
\hline & Other Miscellaneous & Other Miscellaneous \\
\hline
\end{tabular}

\section{- Loss Report}

\begin{tabular}{|c|c|c|}
\hline Category & Offense & Offense Subcategory \\
\hline \multirow{23}{*}{ Loss Report } & CNIC Loss & CNIC Loss \\
\hline & Bay Form Loss & Bay Form Loss \\
\hline & \multirow{2}{*}{ Arm Documents Loss } & Arm License Loss \\
\hline & & Arm Slip Loss \\
\hline & ATM Card Loss & ATM Card Loss \\
\hline & Service Card Loss & Service Card Loss \\
\hline & Passport Loss & Passport Loss \\
\hline & Domicile Loss & Domicile Loss \\
\hline & \multirow{2}{*}{ Driving Documents Loss } & Driving Leaner Loss \\
\hline & & Driving License Loss \\
\hline & Educational Documents Loss & Educational Documents Loss \\
\hline & Ownership Memo Loss & Ownership Memo Loss \\
\hline & \multirow{3}{*}{ Registration Book Loss } & Motor Cycle Registration Book Loss \\
\hline & & Car Registration Book Loss \\
\hline & & Other Vehicle Registration Book Loss \\
\hline & \multirow{3}{*}{ Vehicle Original File Loss } & Motor Cycle Original File Loss \\
\hline & & Car Original File Loss \\
\hline & & Other Vehicle Original File Loss \\
\hline & \multirow{2}{*}{ Cheque } & Cheque Loss \\
\hline & & Cheque Book Loss \\
\hline & Property Documents Loss & Property Documents Loss \\
\hline & Marriage Certificate Loss & Marriage Certificate Loss \\
\hline & Birth Certificate Loss & Birth Certificate Loss \\
\hline
\end{tabular}




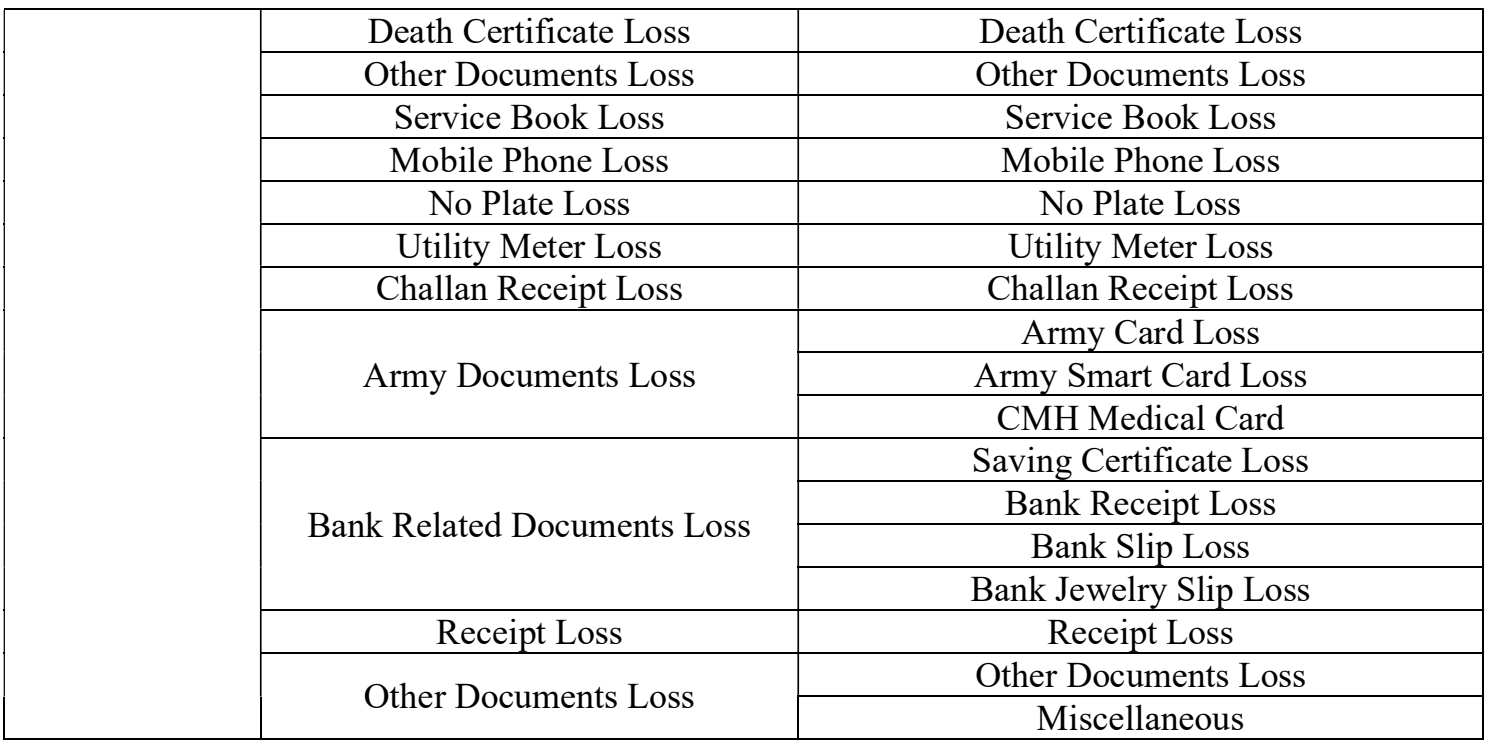

\section{- Character Verification}

\begin{tabular}{|c|c|c|}
\hline Category & Offense & Offense Subcategory \\
\hline Character Verification & Character Verification & Character Verification \\
\hline Employee Verification & Employee Verification & Employee Verification \\
\hline
\end{tabular}

- Investigation

\begin{tabular}{|c|c|c|}
\hline Category & Offense & Offense Subcategory \\
\hline Investigation & Investigation & Investigation \\
\hline
\end{tabular}

The community needs to be aware that they must give any kind of applications at FDs.

\section{CONCLUSION}

The purpose of this research is not to do propaganda or spread negative information about the Punjab police. Punjab police among the other disciplined forces are the most important department that is directly related to the public grievances to ensure peace among society. When the Punjab police department itself is accused of unprofessionalism, violation of rules and non-acceptance behavior toward the FD project then attention to the subject is required. The term "Downfallen of FD" itself seems unjust but it is evident and being happened and enduring in the police department to discuss and study the phenomenon being examined in this paper.

This paper basically highlights different ways or forms in which allegedly police department goes beyond its initiative survival. The biggest role in ruining the FD project is played by high-ups, SO, and finally FD district supervisory. As high-ups failed to implement SOP and JD to empower and monitor FD mechanism, the SO bend the SOP and used FD project for their interests and FD district supervisory failed to perform their duties. Following this objective, different scenarios or justifications have been explored for legitimizing the use of excessive discrimination towards the FD project. As per this study, downfallen of the FD project is usually gained from Administrative Rulers, Departmental Lobbies and Institutionalization Weaknesses which get involved in some sort of institutional decision making and try to interfere official affairs and used them for their personal interests, later on, these lobbies bail them out in one way or the other. If these officials refuse to adhere to such commands then they know they will be either removed or transferred from the current posting. FD is the place where hypothetical and customized data is being entered into the system, without being securing FD supervisory from SO's, the system cannot succeed. To sum up this aspect, we conclude that "There is a threat to police of police", "Police, spoiling the police" and "There is a need of policing in police" which will not let the Punjab police department grow unless police will take prescribed measures. 


\section{FUTURE WORK}

Crime is a widespread problem that affects millions of people around the world. In especially, undeveloped countries like Pakistan, implementation of FD could help to mitigate the crime and public grievance within the police departments. FD could be the backbone of this department.

\section{CONFLICT OF INTEREST}

There is no conflict of interest while writing this research paper.

\section{FUNDING}

This research did not receive any funding from commercial, public or not-for-profit entities.

REFERENCES:-

Applicants, G., Workbook, B. J., Information, B., \& Application, F. (2013). ( M Ay 2013 ). 1-11.

Chattha, S. J., Batool, B., \& Farooq, M. S. (2019). Modernization of Front Desk Project (Fdp) Training Curriculum for Punjab Police. IJAEDU- International E-Journal of Advances in Education, May 2019, 222-230. https://doi.org/10.18768/ijaedu.531553.

Computerization of Police Stations CMS, https://www.pitb.gov.pk/police cms

Ewart, J. M. (1935). Police in India.

Metropolitan Police CJ, 1, 100.

Front Desks Changing Police Face, https://www.punjabpolice.gov.pk/node/4443 Oct 24, 2016.

Front Desk in Punjab Police, https://www.slideshare.net/ranairfan373/front-desk-in-punjab-police Jan 07, 2018.

Front Desk employees, https://dailytimes.com.pk/312392/front-desk-employees-at-police-stations-record-theirplight/ Oct 20, 2018.

Front desk in punjab police, https://www.slideshare.net/ranairfan373/front-desk-in-punjab-police. Front Desk Changing Face, https://punjabpolice.gov.pk/node/4443, 25th November, 2018.

International Crisis Group. (2008). Reforming Pakistan’ S Police. Crisis, July.

Jackson, B. A., Greenfield, V. A., Morral, A. R., \& Hollywood, J. S. (2011). Police Department Investments in Information Technology Systems: Challenges Assessing Their Payoff.

Jackson, B. A., Greenfield, V. A., Morral, A. R., \& Hollywood, J. S. (2011). Police Department Investments in Information Technology Systems: Challenges Assessing Their Payoff.

Laeeq, H., Shahzad, A., Ramalu, S., \& Habiba, U. (2016). An Intervening Role of Organizational Support in The Relationship of Training \& Development And Technological Advancement with The Performance of Punjab Police Pakistan. Journal of Quality and Technology Management, 13(II), 89-113.

Laeeq, H., Shahzad, A., Ramalu, S., \& Habiba, U. (2016). An Intervening Role of Organizational Support in The Relationship of Training \& Development And Technological Advancement with The Performance of Punjab Police Pakistan. Journal of Quality and Technology Management, 13(II), 89-113.

Malik, N., \& Qureshi, T. A. (2020). A Study of Economic, Cultural, and Political Causes of Police Corruption in Pakistan. Policing: A Journal of Policy and Practice, 1-17. https://doi.org/10.1093/police/paaa016

MANNING, P. K. (1992). Technological Dramas and the Police: Statement and Counterstatement in Organizational Analysis. Criminology, 30(3), 327-346. https://doi.org/10.1111/j.1745-9125.1992.tb01107.x

McNabb, D. E. (2013). Research Methods in Public Administration and Nonprofit Management: Quantitative and Qualitative Approaches. $\quad 3$ A.E. Sharpe, 501. http://proxy.kennesaw.edu/login?url=http://search.ebscohost.com/login.aspx?direct=true \&db=edb\&AN=9 $707241962 \&$ site $=$ eds-live $\&$ scope $=$ site

Moullin, M. (2007). Performance measurement definitions: Linking performance measurement and organisational excellence. International Journal of Health Care Quality Assurance, 20(3), 181-183. https://doi.org/10.1108/09526860710743327.

Malik, N., \& Qureshi, T. A. (2020). A Study of Economic, Cultural, and Political Causes of Police Corruption in Pakistan. Policing: A Journal of Policy and Practice, 1-17.

Moullin, M. (2007). Performance measurement definitions: Linking performance measurement and organisational excellence. International Journal of Health Care Quality Assurance, 20(3), 181-183. https://doi.org/10.1108/09526860710743327

Police Initiative, https://punjabpolice.gov.pk/

Punjab Police government of the Punjab, https://punjabpolice.gov.pk/psrms, 25th November, 2018.

Sovacool, B. K., \& Sovacool, B. K. (2019). Technological frames. Visions of Energy Futures, November, 109- 
135. https://doi.org/10.4324/9780367135171-4.

Sparrow, M. (1991) 'Information Systems: A Help or

Hindrance in the Evolution of Policing?', The Police Chief 58(4): 26-44.

Trinkner, R., Kerrison, E. M., \& Goff, P. A. (2019). The force of fear: Police stereotype threat, self-legitimacy, and support for excessive force. Law and Human Behavior, 43(5), 421-435. https://doi.org/10.1037/lhb0000339

Williams, M. P., Srikanth, V., Bird, M., \& Thrift, A. G. (2012). Urinary symptoms and natural history of urinary continence after first-ever stroke-a longitudinal population-based study. Age and Ageing, 41(3), 371-376. https://doi.org/10.1093/ageing/afs009

\section{ACKNOWLEDGEMENT}

History of all great works into a witness that no great work was ever done without either active or passive support of a person surrounding and one's close quarters, thus it not hard to conclude how active assistance from seniors could positively impact the execution of a project. I am highly thankful to our colleague Mr. Muhammad Akmal (PSA) and Muhammad Javeed (ASI) for their active guidance throughout the completion of the paper.

Last but not least, I would also want to extend my appreciation to those who could not be mentioned here but have well played their role to inspire me behind the certain.

\section{APPENDICES}

A: The word "Shafqat" means compassion, in domestic language is that to forgive someone after doing a mistake. In Punjab police, this is a commonly used word.

B: $\quad$ The word "Taki" means forgiveness, in domestic language is to create way or solution for someone after doing a mistake. In Punjab police, this is also a common word used in this department.

\section{SURVEY QUESTIONNAIRE}

Dear Sir/Madam,

I hope this finds you the best in your health.

We're conducting an academic research as part of our Ph.D. Program. This is an academic research survey, which needs some time from your busy schedule. The survey is intended to understand the performance of the Front Desk in Punjab police of Pakistan. Any information that you provide will be kept confidential and used for research purpose only. In this regard, you are requested to kindly fill the survey form as attached herewith. This survey will take about 10 to 15 minutes of your precious time, which will be extremely valuable in fulfilling the requirement of Ph.D. Research.

For your convenience, I have enclosed a self-addressed postage paid envelope for the return of the completed survey. If you have any questions about the survey or the research study, please give us a call or SMS at $(+92-$ 345-7483688) or email at shahidrao739@gmail.com

Your prompt response to this research study will be highly appreciated.

Best Regards,

Muhammad Shahid,

Talha Farooq Khan,

Muhammad Saleem,

Sadia Parveen.

(Ph.D. Scholars)

\section{RESPONDENT'S BACKGROUND}

The following information is strictly confidential and will only be used for research purpose. I will be grateful if you could kindly fill the required information. 
Instruction: Please TICK ( $\square$ ) in the appropriate box

1.

\begin{tabular}{|c|c|}
\hline \multicolumn{2}{|c|}{ Gender } \\
\hline Male & Female \\
\hline
\end{tabular}

2.

\begin{tabular}{c|c}
\multicolumn{2}{c}{ Age } \\
\hline Less than 30 Years & $30-40$ Years \\
\hline $41-50$ Years & 51 Years and Above \\
\hline
\end{tabular}

3.

\begin{tabular}{|c|c|}
\hline \multicolumn{2}{|c|}{ Highest Qualification } \\
\hline MS (M.Phil.) & Masters \\
\hline Bachelors & Intermediate \\
\hline
\end{tabular}

4.

\begin{tabular}{|c|c|}
\hline \multicolumn{2}{|c|}{ Working experience with this department } \\
\hline $1-3$ Years & $4-6$ Years \\
\hline $7-9$ Years & $10-15$ Years \\
\hline More than 15 Years & N/A \\
\hline
\end{tabular}

PART 2

Please read the following statements and TICK ( $\square$ ) the response that closely represents your opinion. The statements are anchored on the following 5 point Likert Scale:

\begin{tabular}{|c|c|c|c|c|c|c|c|c|c|}
\hline \multicolumn{2}{|c|}{ 1: Strongly Agreed } & 2: Agreed & 3:Strongly Disagreed & \multicolumn{3}{|c|}{ 4: Disagreed } & \multicolumn{3}{|c|}{ 5: Neutral } \\
\hline \multicolumn{10}{|c|}{ 6: N/A } \\
\hline No. & \multicolumn{3}{|c|}{ Statements } & SA & $\mathbf{A}$ & SD & $\mathbf{D}$ & $\mathbf{N}$ & N/A \\
\hline 1 & \multicolumn{3}{|c|}{$\begin{array}{l}\text { Police department is responsible to rectify the community } \\
\text { problems }\end{array}$} & 1 & 2 & 3 & 4 & 5 & 6 \\
\hline 2 & \multicolumn{3}{|c|}{$\begin{array}{l}\text { Police department satisfied the citizens regarding complaint } \\
\text { resolution }\end{array}$} & 1 & 2 & 3 & 4 & 5 & 6 \\
\hline 3 & \multicolumn{3}{|c|}{ Police department improved on timeliness of service delivered } & 1 & 2 & 3 & 4 & 5 & \\
\hline 4 & \multicolumn{3}{|c|}{$\begin{array}{l}\text { Police department maintains a good reputation among the } \\
\text { citizens of the Punjab }\end{array}$} & 1 & 2 & 3 & 4 & 5 & 6 \\
\hline 5 & \multicolumn{3}{|c|}{$\begin{array}{l}\text { Police department maintains the high level of motivation } \\
\text { amongst its personals }\end{array}$} & 1 & 2 & 3 & 4 & 5 & 6 \\
\hline 6 & \multicolumn{3}{|c|}{$\begin{array}{l}\text { Police department maintains a healthy and safety environment } \\
\text { for its personals }\end{array}$} & 1 & 2 & 3 & 4 & 5 & 6 \\
\hline 7 & \multicolumn{3}{|c|}{$\begin{array}{l}\text { Police department has a supporting working environment in } \\
\text { obtaining departmental objectives }\end{array}$} & 1 & 2 & 3 & 4 & 5 & 6 \\
\hline 8 & \multicolumn{3}{|c|}{$\begin{array}{l}\text { Police department responds quickly to the citizens if any } \\
\text { incident happens }\end{array}$} & 1 & 2 & 3 & 4 & 5 & 6 \\
\hline 9 & \multicolumn{3}{|c|}{$\begin{array}{l}\text { Police department has successfully developed the procedure to } \\
\text { improve the quality of service offered }\end{array}$} & 1 & 2 & 3 & 4 & 5 & 6 \\
\hline 10 & \multicolumn{3}{|c|}{ Police department did many reforms in respect of digitization } & 1 & 2 & 3 & 4 & 5 & 6 \\
\hline
\end{tabular}

\section{PART 3}

Please read the following statements and TICK ( $\square$ ) the response that closely represents your opinion. The statements are anchored on the following 3 point Likert Scale:
1. True
2. False
3. N/A 


\begin{tabular}{|c|l|c|c|c|}
\hline No. & \multicolumn{1}{|c|}{ Question } & True & False & N/A \\
\hline 1 & Is Front Desk (FD) is independent? & 1 & 2 & 3 \\
\hline 2 & FD staff transfer posting in being made on merit? & 1 & 2 & 3 \\
\hline 3 & Do you think FD staff faces Violation of Merit? & 1 & 2 & 3 \\
\hline 4 & Do you think FD staff faces Violation of SOP? & 1 & 2 & 3 \\
\hline 5 & Is there any favoritism among FD officials? & 1 & 2 & 3 \\
\hline 6 & Any lobbying in department related when it comes to FD? & 1 & 2 & 3 \\
\hline 7 & Is FD staff faces Discrimination? & 1 & 2 & 3 \\
\hline 8 & Do you feel insecurity in department? & 1 & 2 & 3 \\
\hline 9 & Is CMS is effective? & 1 & 2 & 3 \\
\hline 10 & Do you follow proper SOP of FD? & 1 & 2 & 3 \\
\hline 11 & Did you get any departmental threats? & 1 & 2 & 3 \\
\hline 12 & Do you follow SOP for CMS? & 1 & 2 & 3 \\
\hline 13 & Do you have any geographical issues related to transfer posting? & 1 & 2 & 3 \\
\hline 14 & Did police work without getting bribe? & 1 & 2 & 3 \\
\hline 15 & Do you think FDs SOP implemented properly? & 1 & 2 & 3 \\
\hline 16 & Does police needs departmental reforms? & 1 & 2 & 3 \\
\hline 17 & Does police needs professional and ethical training? & 1 & 2 & 3 \\
\hline 18 & Do you think FD providing relief to a general public? & 1 & 2 & 3 \\
\hline 19 & Does police station staff cooperate with FD staff? & 1 & 2 & 3 \\
\hline 20 & Do you think police officials accepted you as a FD official? & 2 & 3 \\
\hline 21 & Does department needs amendments related to FD? & 1 & 3 \\
\hline 22 & Does your salary is enough with the SOP of FD? & 1 & 3 \\
\hline 23 & Do you want to be a permanent employee? & 1 & 2 & 3 \\
\hline 24 & Do you receive stationary on time? & 1 & 2 & 3 \\
\hline 25 & Do you think high-ups paying enough attention to FD project? & 1 & 2 \\
\hline
\end{tabular}

